\title{
Pelatihan Pembuatan Bussiness Plan Bagi Pelaku Umkm Di Kelurahan Mekarsari
}

\author{
Sawqi Saad El Hasan', Marsel Maden², Benediktus Misa ${ }^{3}$, Wahyudi ${ }^{4}$ \\ 1,2,3,4STEBIS Bina Mandiri Cileungsi, Bogor \\ sawqi@binamandiri.ac.id,
}

\begin{abstract}
Abstrak: Untuk menjalani bisnis, kita memerlukan sebuah perencanaan bisnis yang jelas. Seorang pengusaha, organisasi, atau perusahaan tidak luput dari kegagalan pada saat menjalankan bisnisnya karena salah satu penyebabnya adalah tidak adanya rencana bisnis yang jelas. Rencana bisnis dapat menjadi alat ukur yang efektif untuk berbagai jenis bisnis dalam mengatur tujuan-tujuan ke dalam suatu bentuk yang saling berhubungan, terutama bagi pelaku bisnis baru atau bisnis kecil yang baru merintis. Tujuan dari kegiatan pengabdian masyarakat ini adalah untuk menjelaskan setiap aspek dari rencana bisnis bagi pelaku Usaha Mikro, Kecil dan Menengah di Kelurahan Mekarsari. Aspek-aspek tersebut adalah rencana organisasi, rencana pemasaran, analisa keuangan dan dokumen keuangan. Metode penelitian yang digunakan adalah menyampaikan hasil dari studi kepustakaan dan pengalaman bisnis dari narasumber pada saat menekuni usahanya. Hasil dari pengabdian masyarakat ini adalah memberikan peningkatan kemampuan bagi pelaku usaha dalam menyusun rencana bisnis dan keuangan.
\end{abstract}

Kata Kunci: Kewirausahaan, Perencanaan Bisnis, UMKM

\begin{abstract}
To run a business, we need a clear business plan. An entrepreneur, organization, or company does not escape failure when running his business because one of the reasons is the absence of a clear business plan. A business plan can be an effective measuring tool for various types of businesses in organizing goals into an interconnected form, especially for new businesses or small businesses that are just starting out. The purpose of this community service activity is to explain every aspect of the business plan for Micro, Small and Medium Enterprises in Mekarsari Village. These aspects are organizational plans, marketing plans, financial analysis and financial documents. The research method used is to convey the results of the literature study and the business experience of the resource persons when pursuing their business. The result of this community service is to provide increased ability for business actors in preparing business and financial plans.
\end{abstract}

Keywords: Entrepreneurship, Business Plan, SMES

\section{Pendahuluan}

Skala usaha yang ada di Provinsi Jawa Barat pada saat ini masih didominasi oleh Usaha Mikro Kecil (UMK). Menurut data hasil Sensus Ekonomi yang dirilis oleh Badan Pusat Statistik Provinsi Jawa Barat pada tahun 2016, jumlah usaha ini mencapai lebih dari 4,5 juta usaha atau 98,84 persen dari total usaha non-pertanian di Jawa Barat. Berbagai jenis usaha tersebut mampu menyediakan lapangan kerja di Provinsi Jawa Barat lebih dan sudah mencapai angka 9,7 juta orang atau sekitar 74,07 persen dari total tenaga kerja non-pertanian dapat diserap oleh jenis usaha tersebut.

Ketika kita melihat kembali sejarah bangsa Indonesia, keunggulan UMK dapat bertahan dari badai krisis pada tahun 1997-1998 karena berbagai faktor. Faktor yang pertama, biasanya UMK mampu 
menghasilkan barang konsumsi dan jasa yang menyesuaikan dengan kebutuhan masyarakat. Kedua, UMK tidak menggunakan bahan baku impor serta dapat memanfaatkan sumber daya yang ada, baik dari sisi sumber daya manusia, modal, bahan baku dan peralatannya. Ketiga, biasanya bisnis UMKM memiliki modal yang relatif rendah. Oleh karena itu, berdasarkan keunggulan tersebut UMKM dapat bertahan dari dampak pengaruh krisis global yang pada umumnya ditandai dengan penurunan nilai tukar mata uang Rupiah.

Berdasarkan faktor-faktor yang sudah kami ungkapkan di atas, maka kami berinisiatif untuk melaksanakan kegiatan pengabdian masyarakat dengan menyampaikan cara membuat perencanaan bisnis yang akurat dari dasar pengoperasian took baik secara luring dan daring melalui pasar digital (marketplace) dan kemitraan dengan perusahaan jasa ojek daring, hingga terciptanya tujuan bisnis yang realistis. Kerangka dasar bisnis yang akan coba kami kembangkan dalam kegiatan pengabdian masyarakat ini adalah bagaimana membuat dan mendirikan sebuah entitas bisnis dengan konsep toko daring modern yang menjual berbagai macam produk-produk UMKM, menganalisis seluruh kemungkinan peluangpeluang pasar, mengendalikan resiko kerugian serta faktor-faktor pendukung apa saja yang diperlukan agar nantinya bisnis yang dijalani oleh para pelaku UMKM di Kelurahan Mekarsari bisa berjalan lancar dan menghasilkan profit maksimal. Sehingga hasil pengabdian masyarakat ini diharapkan mampu memberikan manfaat untuk para pelaku UMKM di Kelurahan Mekarsari dalam rangka untuk terus meningkatkan pertumbuhan dan pengembangan bisnis dari para pelaku UMKM di Kelurahan Mekarsari.

\section{Metode}

Kegiatan pengabdian masyarakat akan dilakukan dengan dua metode yaitu menyampaikan hasil dari studi kepustakaan dan pengalaman bisnis dari narasumber pada saat menekuni usahanya. Pada kegiatan pengabdian masyarakat ini, kami mengarahkan para pelaku UMKM Kelurahan Mekarsari dalam memilih model dan konsep serta strategi bisnis yang akan digunakan sebagaimana idealnya para pelaku bisnis atau suatu perusahaan harus menyelaraskan antara faktor internal terutama sumber daya dan melihat struktur industri tersebut secara eksternal.

Setelah menganalisis struktur usaha dari faktor eksternal dan kemudian dapat memaksimalkan seluruh komponen sumber daya internal dengan menciptakan berbagai keunggulan. Kemudian setelah hal itu bisa dilakukan maka dapat menyiapkan strategi-strategi untuk bisa mencapai 
tujuan. Strategi yang dimaksud adalah langkah perencanaan yang lebih terukur dan sistematis yang memiliki perbedaan dan ciri khas tersendiri baik dari sisi produk atau jasa yang dihasilkan maupun berdasarkan pada kompetensi dari sumber daya manusia yang dimiliki oleh para pelaku usaha. Hal tersebut berdasarkan Barney (1997), yang menyatakan definisi strategi adalah pola alokasi sumber daya yang memungkinkan organisasiorganisasi untuk dapat mempertahankan kinerjanya. Sedangkan menurut Grant (1995), strategi dapat diartikan sebagai keseluruhan rencana yang berkaitan dengan penggunaan sumber daya-sumber daya untuk menciptakan suatu posisi menguntungkan sehingga perusahaan benarbenar dapat mencapai tujuan yang telah ditetapkan. Sehingga kami selaku tim pengabdian masyarakat dapat mengetahui kebutuhan yang akan dapat disampaikan nantinya pada saat pelatihan pembuatan rencana bisnis diselenggarakan.

Untuk tahapan kegiatan pelatihan ini mencakup berbgaa hal berikut:

1. Fokus Diskusi Kelompok, dimana untuk tahapan ini, tim pengabdi dan pengelola usaha di Kelurahan Mekarsari berdiskusi untuk menemukan kebutuhan pelatihan. Berdasarkan hasil diskusi ini, disepekati pelatihan penyusunan rencana bisnis.

2. Penyusunan Materi Pelatihan. Tim pengabdi bersama narasumber yang merupakan praktisi bisnis yang berpengalaman mendampingi Usaha Mikro Kecil Menengah (UMKM) merumuskan kisi-kisi materi pelatihan. Berdasarkan hasil diskusi, diidentifikasi ruang lingkup materi pelatihan sebagai berikut:

a. penyusunan visi dan misi pelaku usaha

b. pembuatan pelaporan keuangan praktis

c. pemetaan jenis-jenis produk/jasa; dan

d. strategi pemasaran produk/jasa.

3. Pelatihan penyusunan rencana bisnis.

\section{Hasil dan Pembahasan}

Pada saat penyelenggaraan pelatihan pembuatan rencana bisnis, terdapat 10 peserta yang merupakan pelaku UMKM di Kelurahan Mekarsari. Berdasarkan data yang diperoleh pada saat pelatihan, diketahui sebanyak tujuh puluh persen UMKM telah berdiri selama rentang waktu 1-5 tahun. Hal tersebut menunjukkan usaha yang didirikan berarti masih tergolong baru. Kemudian ada 60 persen peserta yang memiliki karyawan kurang dari 5 orang. Hal tersebut merepresentasikan mengenai kondisi peserta karena hampir keseluruhan merupakan usaha mikro. Modal yang dimiliki peserta UMKM sebagian besar kurang dari Rp 50 juta, hanya 2 peserta yang memiliki modal lebih dari itu. Sumber modal umumnya dari 
modal pribadi. Dengan kondisi tersebut menunjukkan bahwa kondisi UMKM masih baru dan bergantung pada model usaha dengan konsep tradisional.

Satu pelaku usaha pada umumnya hanya memiliki satu unit usaha. Hal yang patut dievaluasi berdasarkan diskusi yang dilakukan pada saat pelatihan adalah belum ada satupun yang memiliki badan hukum resmi. Jenis usaha yang banyak dimiliki adalah usaha kuliner yang telah dimiliki oleh 8 pelaku usaha. Unit usaha kuliner ini umumnya melanjutkan Program Nasional Pemberdayaan Masyarakat (PNPM) Mandiri. Bidang usaha selanjutnya yang dijalani salah satu peserta adalah air minum isi ulang. Satu pelaku usaha memiliki unit usaha isi ulang air minim dalam kemasan. Kemudian ada juga salah satu peserta yang memiliki usaha perdagangan dengan memiliki dua warung yang dikelola Bersama dengan anggota keluarganya.

Berdasarkan kondisi di atas dan hasil diskusi dengan peserta, ada suatu pola pikir yang terbentuk di pihak pelaku usaha, apabila suatu usaha sukses dengan 1 jenis unit usaha, maka pelaku usaha lainnya akan membuat model usaha yang sama. Hal ini menyebabkan meningkatnya kompetisi pada satu segmen usaha yang digeluti. Sehingga pola pikir yang terbentuk tersebut menyebabkan sebuah usaha kurang berkembang. $\mathrm{Hal}$ ini juga menunjukkan kurangnya kreativitas para pelaku dan pengelola usaha dalam menciptakan unit usaha baru. Kurangnya perencanaan dan inisitif usaha ini menjadi masalah utama bagi pelaku usaha yang harus ditemukan solusinya.

Selain masalah perencanaan usaha, ada beberapa permasalahan pelaku usaha yang harus segera diselesaikan. Pertama, separuh pelaku usaha merasa belum dapat menyusun laporan keuangan dengan baik. Kedua, beberapa pelaku usaha merasa belum memahami secara menyeluruh cara menjual produk dan menawarkan jasa melalui pasar digital yang sudah tersedia dan menjalin Kerjasama kemitraan dengan pihak ojek daring. Masalah berikutnya adalah kurangnya Sumber Daya Manusia yang berusia muda dan berpendidikan tinggi. Hal ini dapat dilihat dari peserta pelatihan yang lulusan S1 hanya 2 orang dengan 3 orang yang berusia di bawah 30 tahun.

Pelatihan disampaikan oleh tim pengabdi berkolaborasi dengan praktisi bisnis sebagai narasumber. Tim pengabdi menyampaikan materi mengenai penentuan visi-misi organisasi dan teknik penyusunan laporan keuangan praktis. Kemudian dari pihak narasumber praktisi usaha yang sudah berpengalaman menyampaikan materi mengenai pemetaan produk/jasa dan strategi pemasaran serta penjualan. Kolaborasi ini dilakukan sehingga peserta pelatihan mendapatkan wawasan dan masukan 
yang nyata tentang penyusunan rencana bisnis dari masing-masing pelaku usaha.

Kegiatan pengabdian masyarakat terkait dengan penguatan kapasitas usaha kecil telah banyak dilakukan. Pengabdian yang dilakukan oleh Siswanto (2011), dalam kegiatan pengabdian masyarakat yaitu: "Tingkat Manajerial Dan Pengelolaan Keuangan Usaha Mikro, Kecil Dan Menengah (UMKM) di Kab. Kulonprogo", menjelaskan mengenai pengelolaan Usaha Mikro, Kecil Dan Menengah (UMKM) di Kab. Kulonprogo di sisi keuangan, sebagian besar sekitar $54 \%$ masih kurang baik pengelolaannya. Oleh karena itu, diperlukan program pelatihan dan pendampingan, untuk meningkatkan kemampuan pengelolaan keuangan untuk UMKM.

Kemudian menurut Saptono (2016) dalam kegiatan pengabdian masyarakat yang dilakukan dengan judul "Pelatihan Manajemen Usaha dan Pengelolaan Keuangan UKM Bagi Tenaga Kerja Indonesia (TKI) Purna di Sukabumi Jawa Barat" menunjukkan kondisi TKI purna di Sukabumi yang belum memahami dengan baik tentang manajemen usaha dan pengelolaan keuangan. Pelatihan pembuatan manajemen usaha harus diterapkan untuk mengelola keuangan agar efektif serta menjadi sarana informasi dalam pengelolaan usaha. Sehingga para TKI perlu memahami manajemen usaha agar dapat mengatur serta mengelola usaha dengan baik untuk memisahkan keuangan usaha dan pribadi.

Sedangkan menurut Nurlaela (2014) dalam penelitiannya, yaitu: "Kemampuan Menyusun Laporan Keuangan Usaha Kecil Menengah Pengaruhnya Terhadap Kinerja UKM Kerajinan Gitar di kabupaten Sukoharjo" menujukkan pelaku UKM masih minim pengalaman dan kemampuan dalam menyusun laporan keuangan. Sehingga penting bagi pelaku UKM untuk memahami cara menyusun laporan keuangan agar memgetahui perkembangan UKM mereka. Penyusunan laporan keuangan dianggap sangat berpengaruh terhadap kinerja pelaku usaha kecil menengah. menujukkan pelaku UKM masih minim pengalaman dalam menyusun laporan keuangan. Oleh karena itu, penting bagi pelaku UMKM untuk memahami cara menyusun laporan keuangan agar memgetahui perkembangan UMKM mereka. Penyusunan laporan keuangan dianggap sangat berpengaruh terhadap kinerja pelaku UMKM.

Pelatihan perencanaan bisnis yang diselenggarakan mendapatkan sambutan yang cukup positif baik dari peserta maupun pihak Kelurahan Mekarsari. Hal ini ditandai dengan tingkat kehadiran peserta yang cukup tinggi. Peserta betul-betul mengikuti kegiatan pelatihan dari awal hingga akhir secara antusias. Demikian pula pihak kelurahan memberikan dukungan yang tinggi dengan memfasilitasi koordinasi dengan para ketua 
Rukun Warga (RW) untuk mengirimkan pelaku usaha untuk mengikuti kegiatan pelatihan ini.

Kesan yang disampaikan peserta terhadap kegiatan pelatihan adalah positif. Hampir seluruhnya menyatakan optimis mampu untuk menyusun rencana bisnis. Optimisme para pelaku usaha setelah mengikuti pelatihan menjadi sangat penting sebagai pedoman langkah awal dalam membangun kapasitas manajerial pelaku UMKM di Kelurahan Mekarsari. Dalam proses pelatihan terlihat interaksi antara para peserta dengan narasumber untuk menanyakan atau mendiskusikan berbagai permasalahan yang mereka alami dalam mengelola usaha.

Terselenggaranya pelatihan penyusunan rencana bisnis, para peserta mendapatkan penguatan pengetahuan, wawasan dan sikap. Berbagai permasalahan yang dialami oleh pelaku usaha pada dasarnya berakar dari ketiadaan analisis rencana bisnis. Setelah peserta mendapatkan pelatihan mengenai penyusunan rencana bisnis, mereka melaporkan mampu untuk menyusun rencana bisnis. Dokumen rencana bisnis ini memuat visi dan misi, analisis strategi pasar, analisis strategi produk dan jasa yang akan dikembangkan, dan laporan keuangan usaha. Oleh karena itu, rencana bisnis dapat menjadi acuan bagi pelaku usaha untuk mengatasi berbagai permasalahan yang dihadapi dalam mengelola dan menjalani usahanya.

\section{Kesimpulan}

Berdasarkan hasil kegiatan pengabdian yang telah diselenggarakan, dapat disimpulkan bahwa pelatihan ini dapat meningkatkan pengetahuan pelaku usaha dalam menyusun dokumen rencana bisnis. Penyelenggaraan pelatihan ini telah memberikan wawasan dan meningkatkan optimisme bagi pelaku usaha dalam merencanakan bisnis dan keuangan usaha secara akurat. Dampak dari pelatihan ini adalah memberikan peningkatan kemampuan bagi pelaku usaha dalam menyusun rencana bisnis dan keuangan. Pengetahuan dan hasil diskusi pengalaman dari narasumber dan tim pengabdian yang telah dilakukan selama pelatihan ini diharapakan agar para pelaku usaha mampu membuat penyusunan rencana bisnis menjadi pedoman strategis untuk pengembangan bisnis.

Pasca pelatihan, pelaku UMKM Kelurahan Mekarsari sudah bisa membuat proposal perencanaan usaha. Terjadi peningkatan kemampuan dalam pencatatan keuangan bisnis cukup signifikan, setelah dilakukan pelatihan. Pencatatan keuangan bisnis tertata dengan baik, sehingga dapat digunakan sebagai acuan untuk beberapa hal, antara lain: melakukan alokasi keuntungan, alokasi aset, alokasi penambahan modal 
bisnis, alokasi dana untuk penunjang keuangan keluarga, pembayaran zakat, dan penghitungan bagi hasil dengan mitra bisnis.

\section{Refrensi}

Barney, J. B. (1997). Gaining and sustaining competitive advantage. Massachusetts: Addison-Wesley Pub. Co

Grant, R.M, (1995). Contemporary strategy analysis: Concepts, techniques, applications. Second Edition. Cambridge, Massachusetts: Blackwell Pub.

KATALOG POTENSI USAHA MIKRO KECIL PROVINSI JAWA BARAT SENSUS EKONOMI 2016, Bandung: Badan Pusat Statistik Provinsi Jawa Barat

Nurlaela, Siti. (2014). Kemampuan Laporan Keuangan Usaha Kecil Menengah Pengaruhnya Terhadap Kinerja UKM Kerajinan Gitar di Kabupaten Sukoharjo. Jurnal Paradigma. Vol.12. No. 02.

Siswanto. (2011). Tingkat Manajerial Dan Pengelolaan Keuangan Usaha Mikro, Kecil Dan Menengah (UMKM) Di Kab. Kulonprogo. Jurnal Pendidikan Akuntansi Indonesia. Vol. Ix. No. 1.

Saptono, Ari. dkk. (2016). Pelatihan Manajemen Usaha Dan Pengelolaan Keuangan Ukm Bagi Tenaga Kerja Indonesia (TKI) Purna Di Sukabumi Jawa Barat. Jurnal Sarwahita. Vol. 13. No. 1.

\section{Foto Kegiatan}

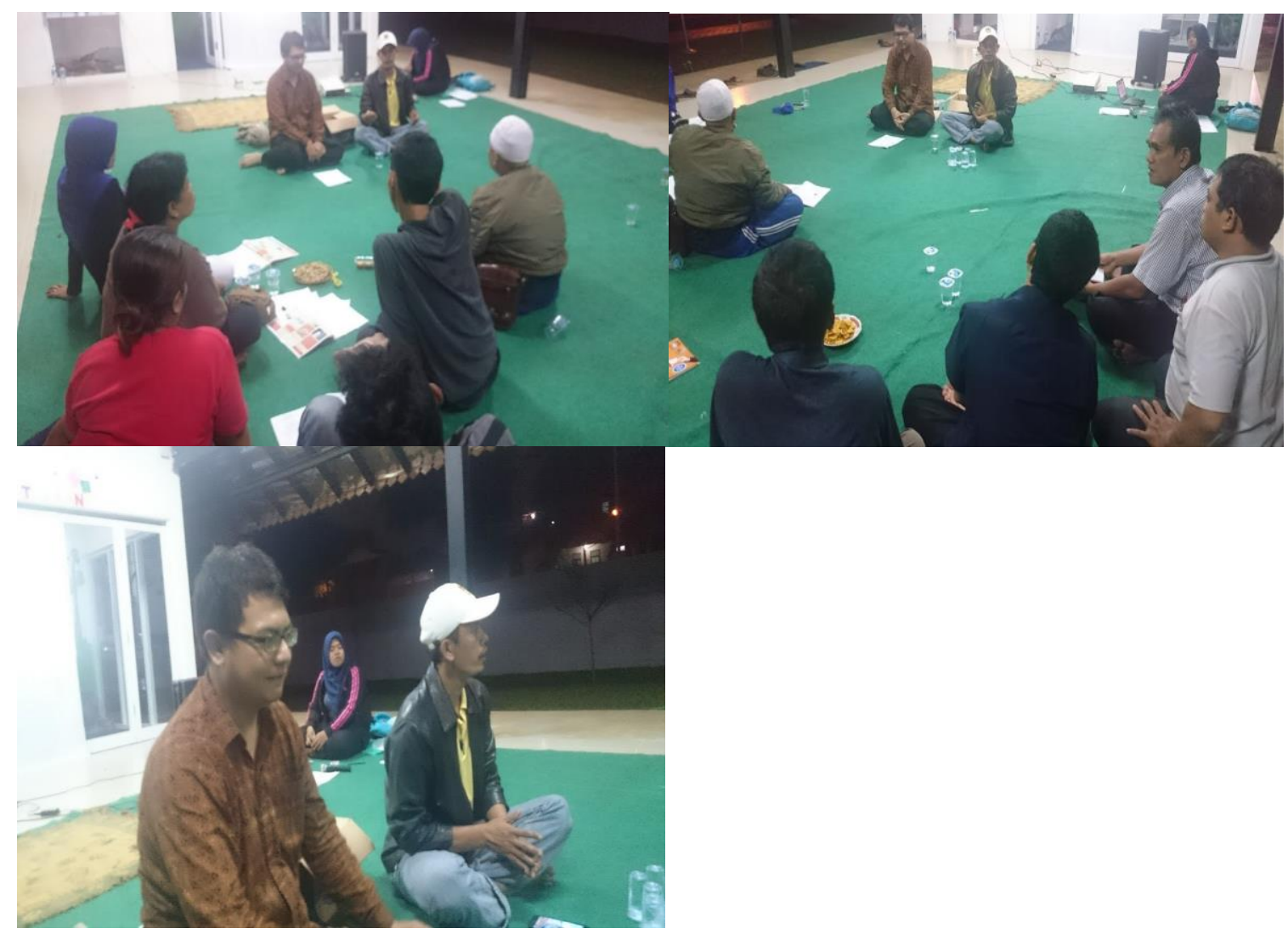

